Humanistika: Jurnal Keislaman

Vol. 7 No 1 2021. Hal. 26-44 ISSN (Print): 2460-5417ISSN (Online): 2548-4400

DOI: https://doi.org/10.36835/humanistika.v7i1.384

\title{
PERAN SPIRITUAL BAGI KESEHATAN MENTAL MAHASISWA DI TENGAH PANDEMI COVID-19
}

\author{
Desti Azania \\ Universitas Islam Negeri Sunan Gunung Djati Bandung \\ Destiazania412@gmail.com \\ Naan \\ Universitas Islam Negeri Sunan Gunung Djati Bandung \\ naan@uinsgd.ac.id
}

\begin{abstract}
In this study, it examines the role of spirituality for the mental bealth of students in the midst of the Covid-19 pandemic. The research subjects were 15 students of Sunan Gunung Djati University with 5 male respondents and 10 female respondents. The data obtained is the result of collecting results using google form with a closed question system. From the results of this study, it can be found that students have a level of anxiety when they are at the beginning of the Covid-19 pandemic, they are threatened with anxiousness to leave the house and interact with other people, but that anxiety is stopped because there are spiritual behaviors experienced by students, one of which is drikir. , almost all respondents carried out health protocols very well in order to break the chain of the corona virus, even students always thought that the covid-19 pandemic would end soon which prevented mental illness that occurred to students and students always filtered the news first for consumption, of course the news was related to the covid-19 virus. Where this is an important role for spirituality and mental health.
\end{abstract}

Keywords::Spirituality, mental health, the covid-19 pandemic.

https://ejournal.unzah.ac.id/index.php/humanistika 


\section{Abstrak}

Penelitian ini mengkaji tentang peranan spiritualitas bagi kesehatan mental mahasiswa ditengah masa pandemi Covid-19. Subjek penelitiannya sebanyak 15 mahasiwa Universitas Sunan Gunung Djati dengan responden laki-laki sebanyak 5 orang dan responden perempuan sebanyak 10 orang. Data yang diperoleh merupakan hasil dari pengumpulan hasil dengan google form dengan sistem pertanyaan yang tertutup. Dari hasil penelitian tersebut dapat diperoleh hasil bahwa mahasiswa mempunyai tingkatan kecemasan saat berada pada awal pandemi covid19 dikerenakan muncul rasa cemas untuk keluar rumah dan berinteraksi dengan orang lain, namun kecemasan tersebut menjadi terhentikan karena adanya perilaku spiritual yang dialami oleh mahasiswa, salah satunya dengan drikir. Hampir seluruh responden melakukan protokol kesehatan dengan sangat baik demi memutuskan rantai virus corona, babkan mahasiswa selalu berpikiran babwa pandemi covid-19 akan segera berakhir yang membuat tidak perjadinya penyakit mental yang terjadi kepada mahaisswa.Mahasiswa selalu menyaring berita terlebib dabulu untuk dicerna tentunya berita tersebut berkaitan dengan virus covid-19. Dimana hal ini menjadi peranan penting bagi spiritualitas dan kesehatan mental.

Kata Kunci :Spiritualitas, kesehatan mental, pandemi covid-19 
Peran Spiritual Bagi Kesehatan Mental Mahasiswa Di Tengan Pandemi Covid-19

\section{PENDAHULUAN}

Kesehatan Mental erat kaitannya dengan istilah sehat dan sakit secara fisik. Penelitian tentang hubungan antara mental individu dan kesehatan fisik telah banyak diungkapkan. Keluhan medis yang mengindikasikan adanya gangguan mental, demikian juga, sakit secara psikis, berpengaruh terhadap kesehatan fisik. ${ }^{1}$ Sehat dan sakit juga merupakan kondisi yang kompleks yang terdiri tubuh biologis, Psikologis dan sosial yang ada dalam satu kondisi. ${ }^{2}$

Dalam lingkup sosial, individu satu dengan lainnya saaing mempengaruhi, ini kemudian disebut dengan itilah Person ini environment. Dinamika sosial terjadi, ketika terjadi pertemuan satu dengan yang lainnya. Manakala salah satu invidu mengalami kesulitan dan akhirnya gagal dalam berinteraksi akan menyebabkan adanya gangguan mental. ${ }^{3}$

Individu sakit baik fisik maupun mental bisa juga diakibatkan oleh dirinya sendiri, tak peduli dengan kesehatannya sendiri dan tidak pandai dalam mengelola waktu yang luang. ${ }^{4}$

Di masa pandemi covid-19 ini, gangguan kesehatan mental menjadi meningkat. Hasil studi yang dipublikasikan oleh Morbidity and Mortality Weekly Report menyatakan bahwa gejala depresi dan gangguan kecemasan di Amerika Serikat meningkat pada bulan April sampai dengan Juni 2020 dibandingkan dengan periode tahun 2019. Anne Thode, seorang terapis di Newyork menyatakan bahwa individu yang memiliki kesehatan mental sebelum masa pandemi covid-19, keadaannya semakin memburuk. ${ }^{5}$

Di Indonesia, dari hari ke hari, jumlah pasien covid-19 terus bertambah. Kondisi ini sangat mempengaruhi kesehatan mental masyarakat,

\footnotetext{
${ }^{1}$ KARTIKA SARI DEWI, Buku Ajar Kesehatan Mental (Semarang: LEMBAGA PENGEMBANGAN DAN PENJAMINAN MUTU PENDIDIKAN UNIVERSITAS DIPONEGORO, 2012), h. 1.

${ }^{2}$ Adisty Wismani Putri, Budhi Wibhawa, and Arie Surya Gutama, "Kesehatan Mental Masyarakat Indonesia (Pengetahuan, Dan Keterbukaan Masyarakat Terhadap Gangguan Kesehatan Mental)," Prosiding Penelitian Dan Pengabdian Kepada Masyarakat 2, no. 2 (2015): 25258, https://doi.org/10.24198/jppm.v2i2.13535, h. 252.

3Putri, Wibhawa, and Gutama.

${ }^{4}$ dkk. Naan, "Kontribusi Sufisme Di Bidang Kesehatan Jiwa Dalam Menghadapi Covid-19," LP2M 1, no. 1 (2020), http://digilib.uinsgd.ac.id/id/eprint/30792.

${ }^{5}$ Dewi Adhitya S. Koesno, "Studi: Penderita Gangguan Mental Meningkat Selama Pandemi COVID-19," Tirto.Id, August 26, 2020, https://tirto.id/studi-penderita-gangguan-mentalmeningkat-selama-pandemi-covid-19-f1uj.
} 
karena Informasi tersebut akan menimbulkan kepanikan dan rasa takut. Masyarakat menjadi merasa tertekan atau terbebani, hingga berdampak nyata bagi kesehatan mental. ${ }^{6}$

Prevalensi kesehatan mental di Indonesia adalah 18,5 \%, yang berarti dari 1.000 penduduk terdapat sedikitnya 185 orang dengan gangguan kesehatan mental atau setiap rumah tangga terdapat seorang anggota keluarga men-derita gangguan kesehatan mental.

Dalam masalah Ibadah, pandemi Covid-19 juga telah memberi dampak pada ritual ibadah orang beragama. Seluruh anggota masyarakat yang biasa beribadah di rumah ibadah seperti Islam ke masjid, Kristen ke Gereja dan Hindu ke Pura, di himbau pemerintah untuk menahan diri datang ke tempat ibadah tersebut, hal ini dimaksudkan untuk menekan kenaikan angka positif covid. Bila pun tetap beribadah di rumah ibadah, maka para ahli ibadah di haruskan untuk menjaga jarak, mencuci tangan dan memakai masker. Hal ini terjadi kepada umat Islam yang kegiatan ibadah salat taraweh di bulan ramadan tahun lalu. Mereka lebih banyak salat taraweh di rumah bersama anggota keluarga lainnya. ${ }^{8}$

Wabah virus corona telah menghambat ibadah orang beragama, lalu bagaimana dengan spiritualitas mereka? asumsi pandangan beberapa orang menyebutkan bahwa hubungan seseorang dengan Tuhannya akan meningkat, karena kesadaran akan mengingat Tuhan menjadi momentum yang tepat. Optimisme harus dimunculkan, agar individu tetap dapat menjaga kesehatannya dengan baik. ${ }^{9}$

${ }^{6}$ dr. Andi Marsa Nadhira, "Menjaga Kesehatan Mental Saat Pandemi Virus Corona," Alodokter.Com, May 27, 2020, https://www.alodokter.com/menjaga-kesehatan-mental-saatpandemi-virus-corona.

${ }^{7}$ Sofwan Indarjo, "Kesehatan Jiwa Remaja," KEMAS: Jurnal Kesehatan Masyarakat 5, no. 1 (2009): 48-57, https://doi.org/10.15294/kemas.v5i1.1860, h. 49.

${ }^{8}$ Desi Purnamawati, "Tetap Ibadah Di Tengah Pandemi COVID-19," Www.Antaranews.Com, April 18, 2020, https://www.antaranews.com/berita/1428909/tetap-ibadah-di-tengahpandemi-covid-19.

${ }^{9}$ Ryman, "Membangun Kesadaran Spiritualitas Dan Optimisme Di Masa Pandemi COVID19," Https://Jendelanasional.Id, August 2020, https://jendelanasional.id/headline/membangun-kesadaran-spiritualitas-dan-optimisme-dimasa-pandemi-covid-19/. 
Peran Spiritual Bagi Kesehatan Mental Mahasiswa Di Tengan Pandemi Covid-19

Pada kelompok yang lebih kecil, remaja, penguatan ibadah menjadi sangat penting. Diharapkan, ibadah dapat menjadi benteng pertahanan jiwa yang efektif dalam menghadapi pandemi covid-19.

Penguatan ibadah dapat menjadi jawaban atas rasa takut, galau, tertekan dan gangguan mental lainnya. Pemerhati jiwa anak UNICEF, Ali Aulia menyatakan bahwa pembatatasan sosial menjadi sebab utama dari rasa takut yang berlebihan yang dialami remaja karena banyaknya informasi covid19 yang mereka terima. ${ }^{10}$

Kecemasan yang menetap pada diri remaja, akan menjadi masalah tersendiri dan dapat menghambat perilakunya dalam menjalankan rutinitas harian. Kegiatan-kegiatan padat yang teradaptasi seperti belajar, bersosial dan ibadah, bila tidak dikelola dengan baik, berdampak psikologis yang membahayakan.

Salah satu penelitian tentang kesehatan mental remaja, dipublikasikan oleh Jurnal Educatio dengan penulis Linda Fitria dan Ifdil dengan judul Kecemasan Remaja pada masa Pandemi Covid-19. Hasil penelitian menunjukkan bahwa tingkat kecemasan remaja di masa pandemi covid 19 masuk dalam kategori tinggi. Saran yang bisa direkomendasikan agar dapat menurun tingkat kecemasan ini dengan layanan konseling, baik individual maupun konseling kelompok. ${ }^{11}$

\section{METODE PENELITIAN}

Penelitian ini masuk dalam kategori kualitatif. Karena di masa pandemi dan mengalami keterbatasan interaksi. Peneliti menggunakan google form untuk memperoleh data yang diinginkan. Data-data yang hendak di gali diantaranya spiritualitas dan kesehatan mental.

Pertanyaan-pertanyaanpenelitian ini dilakukan dengan menggunakan google form ini ditujukan kepada 15 responden dengan jenis 5 pertanyaan

\footnotetext{
${ }^{10}$ Tim Komunikasi Gugus Tugas Nasional, "Lindungi Kesehatan Jiwa Anak Dan Remaja Saat Masa Pandemi COVID-19," https://covid19.go.id, 2020, https://covid19.go.id/p/berita/lindungi-kesehatan-jiwa-anak-dan-remaja-saat-masa-pandemicovid-19.

${ }^{11}$ Linda Fitria and Ifdil Ifdil, "Kecemasan Remaja Pada Masa Pandemi Covid -19," Jurnal EDUCATIO: Jurnal Pendidikan Indonesia 6, no. 1 (2020): 1 , https://doi.org/10.29210/120202592.
} 
tertutup kepada mahasiswa di Universitas Islam Bandung denagn rentang usia 19-23 tahun.

Data-data yang diperoleh kemudian dikumpulkan, dipilah dan dipilih. Reduksi data dibutuhkan untuk mendapatkan hasil penelitian yang tepat.

Dengan demikin, peneliti berharap dapat memgetahui tingkatan spiritualitas mahasiswa dalam mempengaruhi sisi kesehatan mental yang menjadi pengalaman dalam melewati masa Pandemi covid-19..

\section{Hasil dan Pembahasan Spiritual}

Manusia bisa menjadi seorang spiritualis. Spiritualitas dapat diartikan sebagai cahaya dalam diri dengan tujuan untuk mencapaimakna dalam kehidupan.Spiritualitas juga dapat diartikan sebagai bagian yang paling dasar dari kesehatan dan kesejahteraan yang utuh dari dalam diri seseorang. ${ }^{12}$

Carl Gustav Jung menemukan pasien yang sakit secara psikologisdapat sembuh karena telah mengenal agama dan menyembah Tuhannya." "Il Ilmu pengetahuan dan agama adalah sebuah kunci utama yang sangat berharga bagi kehidupan.Sebuah kunci yang dapat digunakan untuk membuka pintu dunia dan mempu mengetahui bahwa hanya Tuhan menciptakan segala sesuatu yang ada. ${ }^{14}$ Dalam perspektif psikologi agama,spiritual diartikan sebagai hal yang paling dasar dari pembahasan agama.Semua kekuatan manusia dapat dikaitkan dengan faktor kepribadian. Intinya bahwa ada sisi energi yang positif secara firik maupun psikologi. ${ }^{15}$

Menurut kamus webster kata spirit bermula dari bahasa latin yang berarti spiritus dengan artinya nafas serta mempunyai kata kerja spirane dengan

\footnotetext{
${ }^{12}$ Abdul Wahid Hasan, SQ Nabi. Aplikasi Strategi Dan Model Kecerdasan Spiritual (SQ) Rasulullulah DiMasa Kini (Yogyakarta: IRCiSod, 2006).

${ }^{13}$ Carl G.Jung, Psikologi Dan Agama (Yogyakarta: IRCiSod, 2017), h. 50.

${ }^{14}$ R.L Piedmont, Does Spirituality Represent the Sixth Factor of Personality? Spiritual Transcendence and the Five-Factor Model.Journal of Personality, (Oxford: Blackwell Publishers, 1999).

${ }^{15}$ Tamami, Psikologi Tasawuf. (Bandung: Pustaka Setia, 2011).
} 
Peran Spiritual Bagi Kesehatan Mental Mahasiswa Di Tengan Pandemi Covid-19 arti sebagai bernafas. ${ }^{16}$ Maka dapat kita artikan bahwa manusia yang hidup bertujuan untuk bernafas serta mempunyai nafas. ${ }^{17}$

Kata spiritualitas memberikan arti sebagai bentuk dasar dari adanya kehidupan itu sendiri. Bahkan spiritualitas merupakan bentuk kesadaran yang ada pada diri manusia serta menjadi bentuk kesadaran manusia dalam menemukan awal mulanya, bahkan tujuannya serta nasib dirinya. ${ }^{18}$

\section{Aspek Spiritualitas}

Dalam mengembangakn konsep spiritualitas sering kali dikenal dengan spiritual transendence.Manusia mempunyai kemampuan untuk mengenal dirinya sendiri dengan segala sesuatu yang berada diluar pengalamnnya.Mengetahui kehidupannya dari sudut pandang yang lebih luas dan tertuju pada sesuatu yang paling dasar dalam memberikan kesimpulan pada alam semesta secara utuh dan mempunyai kesatuan fundamental. Maka aspek spiritual manusia itu antara lain: ${ }^{19}$ (a) Dalam pengalaman beribadah, merupakan sebuah perasaan manusia yang menitikkan pada rasa bahagia dan kegembiraan yang diperoleh ketika dirinya terlibat dalam hal spiritualitas; (b) adanya bentuk keyakinan pada sesuatu yang utuh tentang kehidupan yang terjadi pada alam semesta, atau dikenal dengan universalitas; (c) adanya keyakinan didalam diri manusia akan sesuatu yang berasal dari realitas manusia dalam menembus suatu kelompok tertentu, yang dikenal dengan keterikatan.

Berdasarkan aspek spiritual yang dijelaskan diatas bahwa dapat dijelaskan secara jelas berkaitan dengan ketiga komponen tersebut yang dijabarkan sebagai berikut: ${ }^{20}$ (1) memberikan arti bahwa segala bentuk keyakinan yang terjadi berdasarkan pada sisi keyakinan pada sesuatu yang paling besar dalam mempengaruhi kehidupan manusia serta sangat dibutuhkan demi terciptanya kehidupan manusia yang lebih harmonis, dikenal dengan a sense of connectedness; (2) manusia mampu menggambarkan segala bentuk keyakinan pada kehidupannya sendiri bahkan pada alam semesta, yang dikenal

\footnotetext{
${ }^{16}$ Webster's Seventh New Collegiate Dictionary (G. \& C. Merriam Company, 1963).

${ }^{17}$ Tamami, Psikologi Tasawuf.

${ }^{18}$ Aliah B.P Hasan, Psikologi Perkembangan Islami: Menyingkap Rentang Kebidupan Manusia Dan Perkelabiran Hingga Pascakematian (Jakarta: Raja Grafindo Persada, 2006).

${ }^{19}$ R.L Piedmont, "Spiritual Transendence and the Scientific Study of Spirituality.Journal of Rehabilitation," Alexandria: National Rebabilitation Counseling Association 67, no. 1 (2001): 4-14.

${ }^{20}$ R.L Piedmont, "Strategies for Using the Five-Factor Model of Personality in Religious Research," Journal of Psychology and Theology 27, no. 4 (1999).
} 
dengan Universality; (3) manusia dapat menggambarkan segala bentuk perasaan yang bahagia dan sesuatu yang disukainya yang merupakan hasil dari adanya perjumpaan antara manusia dan religiulitasnya, yang dikenal dengan Prayer Fulfillment.

Pada dua konsep yang dikemukakakn oleh Piedmont dapat dikatakan bahwa sritualitas terdiri dari tiga aspek, yang tergambarkan dengan alat ukur spiritualitas yang kemudian dapat manusia kembangkan. Ada tiga indikator yang mampu menjelaskan tentang perilaku spiritual, yaitu:

a. Adanya sisi pengalaman dalam beribadahnya pada diri manusia, yang kemudian memberikan perasaan bahagia bahkan adanya suka cita dalam terlibatnya diri manusia tersebut ketika manusia tersebut mampu merasakan kekuatan dirinya sendiri serta mampu memberikan manfaat akan ibadah yang dilakukannya.

b. Sebuah bentuk keyakinan yang ada pada manusia dalam bentuk kesatuan serta untuk mencapai tujuan hidupnya, adanya perasaan yang menjelaskan bahwa kehidupannya saling memberikan arti pada keterikatan akan rasa untuk berbagi tanggungjawab antar sesama makhluk yang dicipatakan oleh Tuhannya, yang dikenal dengan Universalitas.

c. Adanya sebuah keinginan yang akan tanggungjawab dirinya sendiri yang berkaitan langsung antar sesama manusia, bahkan adanya sebuah komitmen sesama generasi dan hubungan langsung dengan Tuhannya bahkan komitmen dengan kelompoknya, dikenal dengan istilah keterkaitan.

\section{Faktor berpengaruh dalam spiritualitas}

Spiritualitas merupakan sebuah susunan perkiraan yang penting dalam sisi psikososial yang baik. Adanya bentuk kecenderungan dari sisi kesejahteraan dalam emosi manusia, adanya bentuk psikologis yang dewasa, adanya sebuah gaya interpersonal dan altruistik pada segala sesuatu.Penemuan ini berkaitan 
Peran Spiritual Bagi Kesehatan Mental Mahasiswa Di Tengan Pandemi Covid-19 dengan literatur yang luas dan persoalan kesehatan mental. Spiritualitas mampu membuat manusia ikut serta dalam pemahaman manusia pada hasilnya. ${ }^{21}$

Dysonmemaparkan tiga faktor yang sangat berhubungan langsung dengan sisi spiritualitas manusia, yaitu: ${ }^{22}$ diri sendiri, antar sesama manusia, dan hubungan dengan Tuhan. ${ }^{23}$

Howard mengatakan bahwa adanya satu faktor yang mampu mempengaruhi hubungan spiritualitas seseorang yaitu berawal dari faktor lingkungan. ${ }^{24}$ Bahkan pendapat lain yang dikemukakan oleh Young dengan mengatakan bahwa segala bentuk yang berada didalam kehidupan sekitar seluruh manusia adalah lingkungan. ${ }^{25}$

Spiritualitas diukur melalui kesusksesan seseorang dalam pencariannya akan segala hal yang mampu memberikan makna dalam menggunakan segala bentuk kriteria yang telah berorientasi dalam sisi kebahagiaan. Pengukuran spiritualitas lainnya dengan cara mengukur melalui kesehatan pada mental, fisik, dan kehidupan social. ${ }^{26}$

Pencapaian spiritualitas seseorang yang taat dapat mengantarkan individu pada penyesuaian diri dan menggapai penemuan yang sangat istimewa tanpa batas. ${ }^{27}$

\section{Kesehatan Mental}

Kesehatan mental berasal dari terjemahan dari mental bygiene, kata latinnyamens atau mentisberarti jiwa atau nyawa, sukma, roh dan semangat.Sedangkan bygiene berasal dari kata Yunani yang berarti ilmu yang membahas tuntas tentang kesehatan jiwa seseorang.Itu artinya kesehatan

\footnotetext{
${ }^{21}$ R.L Piedmont, "Cross-Cultural Generalizability of the Spiritual Transcendence Scale to the Philippines:Spirituality as a Human Universal.Mental Health, Religion, and Culture .March," Columbia:Routledge Taylor and French Group 10, no. 2 (2007): 89-107.

${ }^{22} \&$ Koopsen Young, Spritualitas, Kesehatan Dan Penyembuban (Medan: Bina Media Perintis, 2007).

23Djauharul, "Religiusitas,Spiritualitas,Dan Psikologi Positif,” www.google.com, 2013.

${ }^{24}$ dan Howard Steven, 15 Prinsip Dasar Kecerdasan Emosional Meraih Sukses (Bandung: Mizan, 2002).

${ }^{25}$ Young, Spritualitas, Kesehatan Dan Penyembuban.

${ }^{26}$ Asina Rosito, "Spiritualitas Dalam Perspektif Psikologi Positif," Jurnal Visi 18, no. 1 (2010): 29-42.

${ }^{27}$ Saifuddin Aman, Tren Spiritualitas Milenium Ketiga (Tangerang: Ruhama, 2013).
} 
mental merupakan ilmu yang membahas tentang kehidupan jiwa seseorang yang berpandangan bahwa seseorang menjadi agen yang paling sempurna. ${ }^{28}$

Dalam ilmu kedokteran kesehatan mental dapat diartikan sebagai suatu keadaan yang mungkin terjadi pada perkambangan fisik seseorang, atau perkembangan intelektual dan emosi seseorang yang optimal sehingga sangat sejalan dengan keadaan yang terjadi pada orang lain. Oleh sebab itu kesehatan mental mempunyai makna yang sangat serasi dengan sifat manusia dan jika diperhatikan dari segala aspek kehidupan manusia bahkan mempunyai hubungan erat dengan manusia. ${ }^{29}$

Kesehatan mental dapat dipengaruhi karena adanya dua fsktor, yaitu faktor internal yang berasal dari diri seseorang.Internal diri ini tersusun dari kepribadian berupa kondisi fisik, perkembangan, bentuk kematangan, kondisi psikologis, keberagaman, sikap dalam menghadapai permasalahan.Faktor eksternal terdiri dari kondisi perekonomian, adanya kebudayaan,dan kondisi lingkungannya sendiri. ${ }^{30}$

Dapat dikatakan, kesehatan mental merupakan sebuah keadaan yang berkembang secara fisik, sisi intelektual dan sisi emosional yang terjadi pada seseorang serta semakin berkembang seiring dengan tercapainya keselarasan dan adanya pentuk penyesuaian diri antar manusia dengan dirinya sendiri bahkan antara manusia dengan lingkungannya yang bersumber dari adanya sisi iman dan taqwa sehingga dapat tercapainya kehidupan yang bahagia didunia dan kebahagiaan yang terjadi di akhirat.

\section{Aspek yang mempengaruhi kesehatan mental}

Darajat telah membagi aspek kesehatan menjadi menjadi lima aspek, yaitu: (1) tercapainya keselerasan yang terjadi pada fungsi dalam jiwa seseorang; (2) adanya penyesuaian diri manusia dengan dirinya sendiri;(3) adanya

\footnotetext{
${ }^{28}$ Yustinus Semiun, Kesehatan Mental 3 (Yogyakarta: Kanisius, 2006).

${ }^{29}$ Dadang Hawari, Alquran Ilmu Kedokteran Jiwa Dan Kesehatan Mental (Jakarta: Dana Bhakti Yasa, 1997).

${ }^{30}$ Baidi Bukhori, "Kesehatan Mental Mahasiswa Ditinjau Dari Religiusitas Dan Kebermaknaan Hidup.," Psikologika XI, no. 22 (2006): 93-105.
} 
Peran Spiritual Bagi Kesehatan Mental Mahasiswa Di Tengan Pandemi Covid-19 penyesuaian diri dengan lingkungan dan social; (4) berdasarkan pada iman dan taqwa; ( (5) mempunyai tujuan dalam pencapaian sebuah kehidupan yang lebih mempunyai makna dari sisi dunia dan makna di akhirat.

Sedaangkan prinsip kesehatan mental manusia teridiri dari: ${ }^{31}$ nentuk Sikap yang baik yang bisa dilakukan untuk diri sendiri, mampu menyeimbangkan diri, dapat beraktualisasi pada diri, seseorang yang mempunyai kemampuan dalam menerima orang lain, bersosial dan beradaptasi dengan lingkungan, mempunyai ketertarikan dalam tugas dan tertarik dalam pekerjaan, adanya agama, perncanaan masa depan dan sebuah pandangan dalam kehidupan, aturan untuk dirinya, adanya rasa bertanggung jawab dan rasa kebenaran.

Prinsip dalam kesehatan mental menjadi hal paling mendasar yang harus ada dalam diri seseorang agar sehat mentalnya serta tidak terjadi segala bentuk gangguan jiwa. Delapan prinsip tersebut harus ada dalam diri seseorang agar mempunyai mental yang sehat. ${ }^{32}$

\section{Kriteria bagi mental yang sehat}

Sebuah pendapat yang disampaikan oleh Schneiders mengatakan bahwa ada sembilan bentruk kriteria bagi mental yang sehat, yaitu : ${ }^{33}$ mampu menjalankan tugas mental dengan baik, mampu mengendalikan pikiran dan perbuatan, adanya penggabungan motif dan pengendalian masalah bahkan bentuk frustasi secara utuh, bentuk perasan dan bentuk emosi yang sehat, adanya kedamaian dalam pikiran dan beradaptasi dengan kesehatan, perilaku sehat, pandangan tentang diri yang sehat, jati diri ego yang memenuhi syarat, dan hubungan seseorang yang memadai dengan kenyataan hidupnya.

Kesehatan mental mempunyai keterkaitan dengan segala bentuk aspek kepribadian dalam diri seseorang seperti efisiensi mental, bentuk pengendalian dan sisi pembauran yang utuh, bentuk perbuatan dengan mampu mengendalikan setiap permasalahan, perasaan dan emosi yang baik dan bentuk sisi lainnya yang menjadi sembilan aspek dalam mental yang sehat. ${ }^{34}$

\section{Hubungan Spiritual dengan Kesehatan Mental}

\footnotetext{
${ }^{31}$ A.F Jaelani, Penyucian Jiwa Dan Kesehatan Mental (Jakarta: Amzah, 2001). 32Jaelani.

${ }^{33}$ Semiun, Kesehatan Mental 3.

${ }^{34}$ Schneiders, Personal Adjusment and Mental Health (New York: Holt, Rinehart and Winston, 1964).
} 
Kesehatan mental dan spiritualitas memiliki hubungan yang saling berkaitan yaitu adanya bentuk upaya dalam mengembalikan suatu kondisi masalah pada kejiwaan seseorang agar dapat pulih seperti keadaan normal dan mempunyai mental yang lebih sehat. Dalam ajaran Islam spiritual sangat terikat dengan kesehatan jiwa dikarenakan keduanya mempunyai hubungan yang terikat satu sama lain serta kaitannya dengan akhlak dan rasa bahagia bagi manusia. ${ }^{35}$

Konsep kesehatan jiwa dalam Islam dapat dijelaskan seperti berikut ini, Pertama, kitab suci Al-Qur'an sebagai obat bagi setiap penyakit yang terjadi pada manusia.termasuk penyakit mental, sehingga ada hubungan antara penyakit mental dan sisi spiritual manusia. Allah berfirman dalam Al-Qur'an surat Yunus ayat 57 yang artinya Wahai manusia! Sungguh, telah datang kepadamu pelajaran (al-Quran) dari Tuhan-mu, penyembuh bagi penyakit yang ada dalam dada, dan petunjuk serta rahmat bagi orang yang beriman. ${ }^{36}$ ayat ini menunjukkan bahwa Al-Qur'an dapat menjadi panduan bagi manusia dalam mengatasi penyakit yang ada dalam dadanya. Dalam perspektif kajian tasawuf, dada di sini bisa berarti hati yang tingkatannya berada paling luar. ${ }^{37} \mathrm{Kedua}$, Islam memberi tujuan hidup yang jelas, baik di dunia maupun kehidupan di akhirat.Seperti kehidupan manusia di dunia dijelaskan dalam Al-Qur'an surah Al-zariyat ayat 56 dan Al-Baqarah ayat 30.Manusia menjalankan ibadah berdasarkan syariat hukum Islam, maka hal itu memberikan manfaat dalam penyembuhan penyakit mental.Ketiga, Agama Islam memberikan saran bagi umatnya untuk selalu sabar dan menjalankan perintah shalat ketika sedang diberikan cobaan oleh Allah. Seperti yang dijelaskan dalam Al-Qur'an surah AlBaqarah ayat 153 yang artinya, Wahai orang-orang yang beriman! Mohonlah pertolongan (kepada Allah) dengan sabar dan shalat. Sungguh, Allah beserta orang-orang yang sabar. In jalan terbaik, berusaha, shalat dan bersabar. Orang yang shalat dan senantiasa bersabar dalm menghadapi situasi apapun, adalah

\footnotetext{
${ }^{35}$ Sarlito W Sarwono, Pengantar Psikologi Umum (Jakarta: Raja Grafindo Persada, 2009).

${ }^{36}$ Ibnu Abbas, Al-Kalam (Bandung: CV. Diponegoro, n.d.).

${ }^{37}$ Andi Nurlaela Naan Naan, "Struktur Insan Sebagai Konsep Kepribadian Manusia Perspektif Sufi," Esoterik: Jurnal Akblak Dan Tasawuf 6, no. 2 (2020): 217-34, https://doi.org/10.21043/esoterik.v6i2.7083.
} 
Peran Spiritual Bagi Kesehatan Mental Mahasiswa Di Tengan Pandemi Covid-19 orang yang memiliki mental yang sehat. Keempat, Islam menyarankan agar seluruh umatnya untuk berzikir hanya kepada Allah jika ingin memperoleh hati yang tenang dari berzikir.Kelima, Islam memberikan tuntunan mengelola kekayaan. Harta tidak harus menjadikan seseorang menjadi sombong, namun harus senantiasa bersyukur atas apa yang telah Allah berikan tanpa pernah meminta sesuatu yang lebih dan menerima semua yang Allah berikan.Keenam, Seorang mmuslim seyogyanyaberhati bersih dan suci.Seluruh tindakannya disebabkan karena Allah dan meninggalkan yang dilarang agama juga karenaNya. Ketujuh, Nabi Muhammad adalah teladan hidup. Semua ajaran yang dibawanya, tindakan yang lakukannya, menjadi contoh yang baik untuk diikuti.

Penjelasan diatas tidak mewakili semua pandangan ajaran Islam tentang kesehatan mental, peneliti dapat mengungkap lebih luas lagi, tentang kontribusi ajaran Islam terhadap kesehatan mental. Dengan melakukan sebuah pengkhayatan dan pengamalan ajaran Islam, membuat seseorang mampu mendapatkan rasa bahagia dan sejahtera secara mental.Islam peduli pada perawatan mental dan pengobatannya.Islam adalah fitrah yang sangat penting bagi spiritualitas manusia. ${ }^{38}$

\section{Kesehatan Mental Ditengah Pandemi Covid'19}

Ditengah pandemi seperti saat ini, kegelisahaan dan ketakutan telah membuat mental seseorang menjadi terganggu. Individu harus dapat mengendalikan dirinya agar hidup tetap sehat, baik sehat fisik maupun sehat secara mental. Sehat mental memberikan arti bahwa suatu keadaan seseorang yang sedang dalam kondisi baik bahkan dapat mengembangkan bakat yang ada pada dirinya serta dapat melewati setiap bentuk tekanan dalam kehidupan yang dijalaninya bahkan mampu ikut serta membantu lingkungan dia dalam bersosial. ${ }^{39}$

Menurut WHO, adanya bentuk stres yang timbul akibat dari pandemi Covid-19, karena beberapa hal berikut:

\footnotetext{
${ }^{38}$ Musbikin, Sholeh, Moh., Agama Sebagai Terapi (Yogyakarta: Pustaka Pelajar, 2005).

${ }^{39}$ WHO, "Mental Health During Covid-19 Pandemic," www.cdc.gov, 2019, https://www.cdc.gov/coronavirus/2019-ncov/daily-life-coping/managing-stress-anxiety.html.
} 
1. Timbulmya sisi ketakutan bahkan adanya rasa cemas akan terganggunya kesehatan untuk diri sendiri dan kesehatan yang terjadi pada orang yang dia sayangi.

2. Kurangnya istirahat dan mengkonsumsi makanan yang tidak sehat

3. Insomnia dan terganggunya sisi konsentrasi seseorang

4. Memperburuk keadaan fisik yang terjadi pada seseorang dengan riwayat penyakit serius yang dimilikinya atau penyakit mental yang telah dideritanya.

5. Menggunakan narkoba

Sehat secara mental dapat diupayakan. Setiap orang dapat meraih kesehatan mental dengan gratis. Berikut beberapa hal yang bermanfaat dan dapat membuat mental individu menjadi sehat. Pertama, Mindfulluness. Mindfulness merupakan bentuk keadaan ketika pikiran seseorang bahkan perasaan dan fisik seseorang sedang dalam keadaan tidak mengingat masa lalu atau menyusun rencana masa depan. ${ }^{40} \mathrm{Kedua}$, Guided Imagery, Seseorang disarankan untuk menutup kedua mata kemudian membayangkan segala sesuatu yang sangat membuat dirinya merasakan kebahagiaan yang bertujuan untuk meningkatkan sisi imajinasi dalam diri seseorang. Walaupun hal ini hanya bersifat sementara akan tetapi mampu menjadi pertolongan pertama pada mental seseorang yang sedang mengalami kecemasan yang berlebihan akan sesuatu. Ketiga, Self-Talk. Berbicara dengan diri sendiri yang menggunakan kalimat baik, sehingga emosi kita dapat dipengaruhi dengan apa yang kita pikirkan serta mempunyai keterikan akan segala sesuatu peristiwa yang kita tafsirkan. Keempat,Ekspressive Writting. Menenangkan pikiran serta adanya perasaan yang tenang atas apa yang menjadi pengalaman kita selama masa pandemi covid-19 yang kemudian kita curahkan dalam bentuk tulisan.

\section{Hasil Penelitian}

Berdasarkan pemaparan materi yang berkaitan dengan hasil penelitian yang diakukan pada 14-15 October 2020 dalam bentuk google form.Hasil dari

\footnotetext{
${ }^{40}$ Kabat-Zinn J, Full Catastrophe Living: Using the Wisdom of Your Body and Mind to Face Stress, Pain, and Illness (New York: Dell Publishing, 1990).
} 
Peran Spiritual Bagi Kesehatan Mental Mahasiswa Di Tengan Pandemi Covid-19 penelitian ini dilakukan dengan data yang akurat ditujukan kepada 15 responden. Dengan bentuk 5 pertanyaan tertutup.

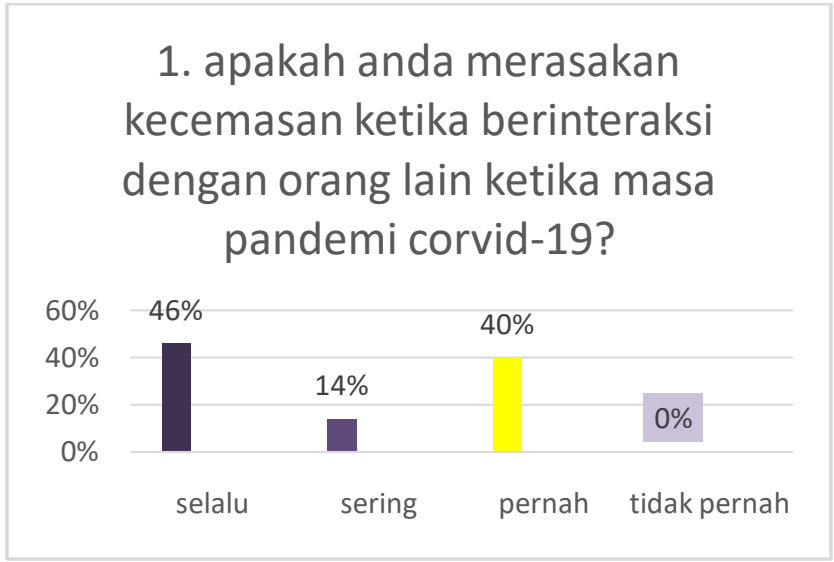

Berdasarkan tabel diatas maka ada $46 \%$ responden yang mengaku selalu mengalami kecemasan dalam berinteraksi dengan orang lain ketika pandemi, 14\% responden mengaku sering mengalami kecemasan dalam berinteraksi dengan orang lain ketika pandemi, 40\% responden mengaku pernah mengalami kecemasan dalam berinteraksi dengan orang lain ketika pandemi dan tidak ada responden yang tidak pernah mengalami kecemasan dalam berinteraksi dengan orang lain ketika pandemi.

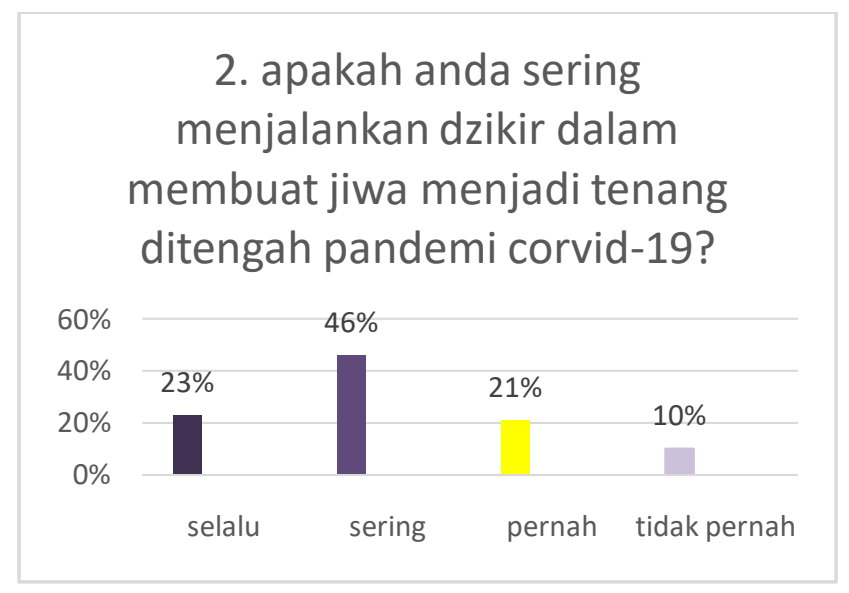

Tabel diatas menyebutkan bahwa 23\% responden mengaku selalu menjalankan dzikir agar jiwa tenang dimasa pandemi covid-19, 46\% responden sering menjalankan dzikir agar jiwa tenang dimasa pandemi covid-19, 21\% 
responden mengaku pernah menjalankan dzikir agar jiwa tenang dimasa pandemi covid-19 dan 10\% responden mengaku tidak pernah menjalankan dzikir agar jiwa tenang dimasa pandemi covid-19.

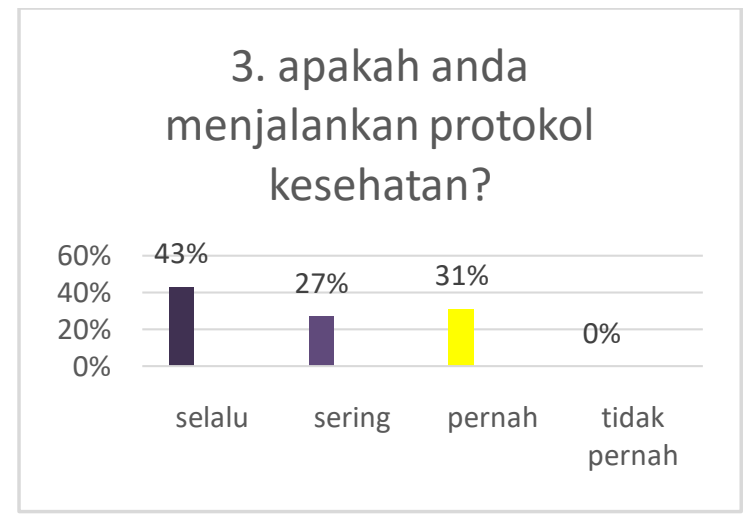

Berdasarkan tabel diatas dapat disimpulkan jika ada $43 \%$ responden mengaku selalu menjalankan protokol kesehatan, 27\% responden mengaku sering menjalankan protokol kesehatan, 31\% responden mengaku pernah menjalankan protokol kesehatan dan tidak ada yang tidak pernah menjalankan protokol kesehatan.

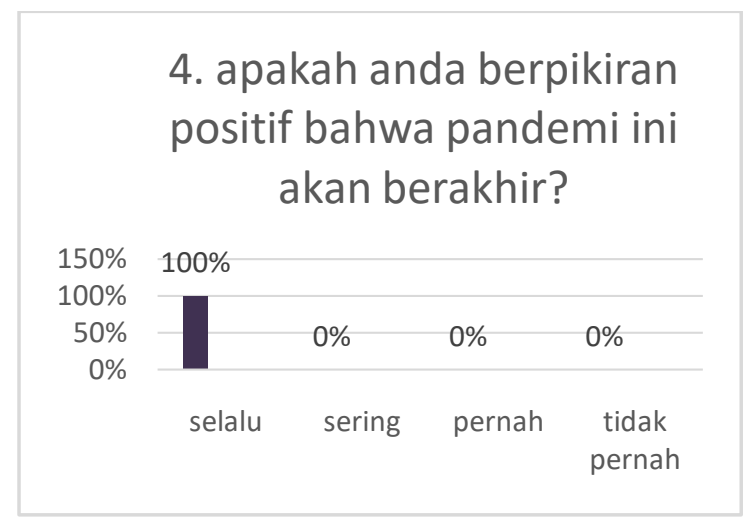

Berdasarkan tabel diatas dapat dijelaskan bahwa 100\% responden selalu berpikiran positif jika pandemi ini akan berakhir. 
Peran Spiritual Bagi Kesehatan Mental Mahasiswa Di Tengan Pandemi Covid-19

5. apakah anda menyaring

informasi terlebih dahulu

tentang cirvid-19?

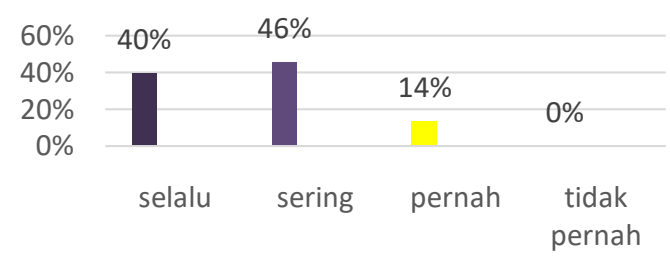

Berdasarkan tabel diatas dapat dijelaskan bahwa $40 \%$ responden selalu menyaring informasi tantang covid-19, 46\% responden sering menyaring informasi tentang covid-19, 14\% responden mengaku pernah menyaring berita tentang covid-19 dan tidak ada responden yang tidak pernah menyaring bersita tentang covid-19.

\section{Kesimpulan}

Berdasarkan hasil penelitian yang telah di lakukan dapat diambil kesimpulan bahwa mahasiswa telah melakukan kegiatan yang menghasilkan nilai-nilai spiritualitas dalam menunjang kesehatan mentalnya ditengah pandemi covid-19.Kegiatan zikir sebagai olah spiritual membuat mahasiswa menjadi lebih tenang dalam mengontrol diri sendiri bahkan mampu merangkul orang lain dalam menangani tingkatan kecemasan akibat covid-19.Seluruh mahasiswa mempunyai pikiran yang positif dan yakin jika masa pandemi covid19 ini akan segera berakhir. Dengan keyakinan ini pikiran negatif tidak akan terjadi sehingga mampu menjaga kesehatan mental bagi mahasiswa. Banyak mahasiswa yang menyaring informasi terlebih dahulu tentang pandemi covid19, dikarenakan hal ini juga menjadi sebuah acuan bahwa pandemi ini akan segera berakhir dan tidsk akan menimbulkan kepanikan berlebihan untuk diri sendiri dan orang lain. 
Desti Azania, Naan

\section{REFERENCE/DAFTAR PUSTAKA}

Abdul Wahid Hasan. SQ Nabi. Aplikasi Strategi Dan Model Kecerdasan Spiritual (SQ) Rasulullulah DiMasa Kini. Yogyakarta: IRCiSod, 2006.

Aman, Saifuddin. Tren Spiritualitas Milenium Ketiga. Tangerang: Ruhama, 2013.

Bukhori, Baidi. "Kesehatan Mental Mahasiswa Ditinjau Dari Religiusitas Dan

Kebermaknaan Hidup.” Psikologika XI, no. 22 (2006): 93-105.

Carl G.Jung. Psikologi Dan Agama. Yogyakarta: IRCiSod, 2017.

Dadang Hawari. Alquran Ilmu Kedokteran Jiwa Dan Kesebatan Mental. Jakarta:

Dana Bhakti Yasa, 1997.

Desi Purnamawati. "Tetap Ibadah Di Tengah Pandemi COVID-19." Www.Antaranews.Com. April 18, 2020. https://www.antaranews.com/berita/1428909/tetap-ibadah-di-tengahpandemi-covid-19.

Dewi Adhitya S. Koesno. "Studi: Penderita Gangguan Mental Meningkat Selama Pandemi COVID-19." Tirto.Id. August 26, 2020. https:/ / tirto.id/studi-penderita-gangguan-mental-meningkat-selamapandemi-covid-19-f1uj.

Djauharul. "Religiusitas,Spiritualitas,Dan Psikologi Positif." www.google.com, 2013.

dr. Andi Marsa Nadhira. "Menjaga Kesehatan Mental Saat Pandemi Virus Corona." Alodokter.Com. May 27, 2020. https://www.alodokter.com/menjaga-kesehatan-mental-saat-pandemivirus-corona.

Fitria, Linda, and Ifdil Ifdil. "Kecemasan Remaja Pada Masa Pandemi Covid 19." Jurnal EDUCATIO: Jurnal Pendidikan Indonesia 6, no. 1 (2020): 1. https://doi.org/10.29210/120202592.

Hasan, Aliah B.P. Psikologi Perkembangan Islami: Menyingkap Rentang Kehidupan Manusia Dan Perkelabiran Hingga Pascakematian. Jakarta: Raja Grafindo Persada, 2006.

Ibnu Abbas. Al-Kalam. Bandung: CV. Diponegoro, n.d. Jaelani, A.F. Penyucian Jiwa Dan Kesehatan Mental. Jakarta: Amzah, 2001. Kabat-Zinn J. Full Catastrophe Living: Using the Wisdom of Your Body and Mind to Face Stress, Pain, and Illness. New York: Dell Publishing, 1990. 
Peran Spiritual Bagi Kesehatan Mental Mahasiswa Di Tengan Pandemi Covid-19

KARTIKA SARI DEWI. Buku Ajar Kesehatan Mental. Semarang: LEMBAGA

PENGEMBANGAN DAN PENJAMINAN MUTU PENDIDIKAN UNIVERSITAS DIPONEGORO, 2012.

Naan, dkk. "Kontribusi Sufisme Di Bidang Kesehatan Jiwa Dalam Menghadapi Covid-19.” LP2M 1, no. 1 (2020). http://digilib.uinsgd.ac.id/id/eprint/30792.

Naan Naan, Andi Nurlaela. "Struktur Insan Sebagai Konsep Kepribadian Manusia Perspektif Sufi." Esoterik: Jurnal Akblak Dan Tasawnf 6, no. 2 (2020): 217-34. https://doi.org/10.21043/esoterik.v6i2.7083.

Nasional, Tim Komunikasi Gugus Tugas. "Lindungi Kesehatan Jiwa Anak Dan Remaja Saat Masa Pandemi COVID-19.” https://covid19.go.id, 2020. https://covid19.go.id/p/berita/lindungi-kesehatan-jiwa-anak-danremaja-saat-masa-pandemi-covid-19.

Piedmont, R.L. "Cross-Cultural Generalizability of the Spiritual Transcendence Scale to the Philippines:Spirituality as a Human Universal.Mental Health, Religion, and Culture .March." Columbia:Routledge Taylor and French Group 10, no. 2 (2007): 89-107.

- Does Spirituality Represent the Sixth Factor of Personality? Spiritual Transcendence and the Five-Factor Model.Journal of Personality,. Oxford: Blackwell Publishers, 1999.

"Spiritual Transendence and the Scientific Study of Spirituality.Journal of Rehabilitation." Alexandria: National Rehabilitation Counseling Association 67, no. 1 (2001): 4-14.

"Strategies for Using the Five-Factor Model of Personality in Religious Research.” Journal of Psychology and Theology 27, no. 4 (1999).

Putri, Adisty Wismani, Budhi Wibhawa, and Arie Surya Gutama. "Kesehatan Mental Masyarakat Indonesia (Pengetahuan, Dan Keterbukaan Masyarakat Terhadap Gangguan Kesehatan Mental)." Prosiding Penelitian Dan Pengabdian Kepada Masyarakat 2, no. 2 (2015): 252-58. https://doi.org/10.24198/jppm.v2i2.13535.

Rosito, Asina. "Spiritualitas Dalam Perspektif Psikologi Positif." Jurnal Visi 18, no. 1 (2010): 29-42.

Ryman. "Membangun Kesadaran Spiritualitas Dan Optimisme Di Masa Pandemi COVID-19." Https://Jendelanasional.Id. August 2, 2020. https://jendelanasional.id/headline/membangun-kesadaran-spiritualitas- 
dan-optimisme-di-masa-pandemi-covid-19/.

Sarwono, Sarlito W. Pengantar Psikologi Umum. Jakarta: Raja Grafindo Persada, 2009.

Schneiders. Personal Adjusment and Mental Health. New York: Holt, Rinehart and Winston, 1964.

Semiun, Yustinus. Kesehatan Mental 3. Yogyakarta: Kanisius, 2006.

Sholeh, Moh., dan Musbikin. Agama Sebagai Terapi. Yogyakarta: Pustaka Pelajar, 2005.

Sofwan Indarjo. "Kesehatan Jiwa Remaja." KEMAS: Jurnal Kesehatan

$\begin{array}{lllll}\text { Masyarakat } & 5, & \text { no. } & 1 & \text { (2009): }\end{array}$ https://doi.org/10.15294/kemas.v5i1.1860.

Steven, dan Howard. 15 Prinsip Dasar Kecerdasan Emosional Meraib Sukses. Bandung: Mizan, 2002.

Tamami. Psikologi Tasawnf. Bandung: Pustaka Setia, 2011.

Webster's Seventh New Collegiate Dictionary. G. \& C. Merriam Company, 1963.

WHO. "Mental Health During Covid-19 Pandemic." www.cdc.gov, 2019. https://www.cdc.gov/coronavirus/2019-ncov/daily-lifecoping/managing-stress-anxiety.html.

Young, \& Koopsen. Spritualitas, Kesehatan Dan Penyembuban. Medan: Bina Media Perintis, 2007. 